\title{
ASYLUM IN THE INTER-AMERICAN SYSTEM: A SOVEREIGN STATE LAW OR AN INHERENT RIGHT OF THE HUMAN PERSON?
}

\author{
O ASILO NO SISTEMA INTERAMERICANO: UM DIREITO \\ SOBERANO DO ESTADO OU UM DIREITO INERENTE À PESSOA \\ HUMANA?
}

SIDNEY GUERRA

Post-Doctorate from the Center for Social Studies, University of Coimbra; PostDoctorate by the Advanced Program in Contemporary Culture of the Federal University of Rio de Janeiro (UFRJ). Doctor and Master of Law. Associate Professor at the Federal University of Rio de Janeiro. Full Professor at the University of Grande Rio and Associate Professor at Mackenzie Rio Presbyterian College. Visiting Researcher at Stetson University Law School. President of the Brazilian Peacemaker Institute (IBP). Lawyer. Contact: sidneyguerra@terra.com.br

\begin{abstract}
Objective: The aim of this research is to present and discuss the paradox of the right of asylum for refugees, considering that on one hand there is a right of protection of the human being, giving priority to the fundamental values of freedom and the protection to be afforded to political refugees and persons persecuted for political reasons and, on the other hand, there is the prerogative and sovereignty of each State.

Methodology: The research was developed in deductive method, in bibliographic research, through interpretation of scientific articles, studies and jurisprudence, also seeking a historical perspective, as well as the interpretation of Brazilian legislation, comparative law and international bodies such as the Inter-American Court of Human
\end{abstract}


Rights, the Asylum Convention, signed in Havana in 1928, the Cartagena Declaration, the Caracas Convention of 1954 and others.

Results: The study reaches the conclusion that the right to asylum still has a very incipient treatment, as it is still considered a right of the State and not the right of the individual, despite its essential purpose of protecting the individual, which is considered a contradiction. This paradox is more evident when the prerogative of the State to grant asylum or not is confronted with the Universal Declaration of Human Rights.

Contributions: Undoubtedly, this matter is currently relevant as it deals with international human rights and the expectation of millions of migrants hoping to obtain an asylum. As a contribution, this article reports several difficulties associated with the granting of an asylum in the national perspective as well as international cases and all efforts exercised by international bodies in favor of the refugees.

KEYWORDS: Right of asylum; territorial asylum; political asylum; Interamerican Human Rights Court.

\section{RESUMO}

Objetivo: O objetivo desta pesquisa é apresentar e discutir o paradoxo do direito de asilo para refugiados, considerando que, por um lado, há o direito à proteção do ser humano, priorizando os valores fundamentais da liberdade e da proteção à saúde, a ser concedido a refugiados políticos e pessoas perseguidas por razões políticas e, por outro lado, há a prerrogativa e a soberania de cada Estado.

Metodologia: A pesquisa foi desenvolvida com método dedutivo, em pesquisa bibliográfica, através da interpretação de artigos científicos, estudos e jurisprudência, buscando também uma perspectiva histórica, bem como a interpretação da legislação brasileira, direito comparado e organismos internacionais como o Interamericano Tribunal Interamericano de Direitos Humanos, a Convenção de Asilo, assinada em Havana em 1928, a Declaração de Cartagena, a Convenção de Caracas de 1954 e outras.

Resultados: $O$ estudo conclui que o direito de asilo ainda tem um tratamento muito incipiente, pois ainda é considerado um direito do Estado e não um direito do indivíduo, apesar de seu objetivo essencial de proteger o indivíduo, o que é considerado um contradição. Esse paradoxo é mais evidente quando a prerrogativa do Estado de conceder ou não asilo é confrontada com a Declaração Universal dos Direitos 


\section{Humanos.}

Contribuições: Sem dúvida, este assunto é relevante no momento, pois trata dos direitos humanos internacionais e da expectativa de milhões de migrantes que esperam obter um asilo pelos mais variados motivos. Como contribuição, este artigo relata várias dificuldades associadas à concessão de asilo em perspectiva nacional, bem como casos internacionais e todos os esforços exercidos por organismos internacionais a favor dos refugiados.

PALAVRAS-CHAVE: Direito de asilo; asilo territorial; Asilo político; Corte Interamericana de Direitos Humanos.

\section{INTRODUCTION}

The right of asylum's study is of great interest, as is associated to the human person. It presents itself in two modalities: the diplomatic, as disposed in art. $1^{\circ}$ of the OAS Charter, of March 28 of 1954; and the territorial asylum, foreseen in the Convention on Territorial Asylum, of 1954.

Even with the evolution of international law and the consequent strengthening of international human rights law, the institute, despite seeking to establish protection for the individual, has in practice proved to be a prerogative of states and is regarded (the diplomatic asylum and the territorial), often as a mere faculty of the state.

The practice of this institute, as characteristic of a State of Law, must have in its essence the fundamental values of freedom and protection to be afforded to political refugees and persons persecuted for political reasons or crimes in legations, warships, encampments and Military aircraft.

Regarding the legitimacy of territorial asylum and diplomatic asylum, it is recognized, in relation to the first one, everywhere, while in diplomatic asylum its regulation has achieved greater development and consecration in Latin America, given the political instability and constant breaches of legality by military authoritarian 
regimes, fact that led to its regular practice in such region, where it emerged as a customary institution in the nineteenth century. From then on, the asylum gained more vitality, which culminated in an institution characteristic of conventional Latin American law.

The asylum right also leads to reflection on its effects on the international order, as seen from the perspective of asylum interference with extradition, which can often lead to the problem of disguised extradition.

As it is an international protection to the elementary guarantees of the endangered human being and extends its reflexes to the international legal order, asylum right is of relevant importance not only in international law but also in domestic law as regards to the fundamental notion of freedom.

This discussion returns strongly on the American continent, following the recent manifestation of the Inter-American Court of Human Rights, due to the provocation of the Republic of Ecuador, through Advisory Opinion n. 25, of May 30, 2018. Thus, this article will contemplate some general aspects about the institute of territorial and diplomatic asylum, in order to present, finally, the understanding of the Inter-American Court in this matter.

\section{THE TERRITORIL ASYLUM}

Territorial asylum was upheld in Article XIV of the Universal Declaration of Human Rights by stating that "every man who is a victim of persecution has the right to seek and to enjoy asylum in other countries".

Currently, not only the political criminal beneficiates from this concession, in line with article 1st of the OAS Convention on Territorial Asylum, of 1954, but also refugees in general, as it can be observed: 
"Every State has the right, in the exercise of its sovereignty, to admit into its territory such persons as it deems advisable, without, through the exercise of this right, giving rise to complaint by any other State."1.

Article $3^{\text {rd }}$ of the same convention of the same Convention dealt with the most basic principle of the 1951 Convention on the Status of Refugees, the non-refoulement, which consists of a rule that a person cannot be refused to the country of origin by the administrative authorities of the country to which intends to take refuge.

However, despite the fact that refoulement sealing is currently considered as a principle of general international law, many countries violate it, based on article $2^{\text {nd }}$ of the Declaration on Territorial Asylum, which states that, in the case of national security or to protect the population, as in the case of a mass influx of people, may not receive refugees, such as so-called boat-people, particularly in Vietnam, but a further consequence of be considered a right of the human person.

In practice, when a refugee goes to another state, if it does not want to accept him, it has two alternatives: to return him to the state from which he came, or to send him to a third state. In any case, the first solution still violates the non-refoulement principle. In the case of maritime refugees, what actually happens when the refugee is compelled to embark again is deportation, as he / she has entered and remained in another country's territory for a brief period of time.

A person who receives territorial asylum, as provided for in the OAS Convention of Territorial Asylum, has the right to freedom of expression, thought, and assembly or association, and must be kept at a certain distance from the borders of the territorial state in the case of persons with high peril. It is also allowed to leave the

\footnotetext{
${ }^{1}$ CAVARZERE, 2001, p. 93, valendo-se das palavras do secretário comissariado das nações unidas, definiu os refugiados da seguinte forma: "A refuge is commonly defined as any person who is oblighed to flee his habitual place of residence and seek refugee elsewhere. This situation may result from two fundamentally different types of events: a natural disaster such as an earthquacke or a flood, or what is referred to nowadays as a 'man-made' disaster such as any international armed conflict, civil-war, revolution or persistent general socio-political instability".
} 
asylum from the asylum state as long as it warns the Government and does not go to the country from which they came. ${ }^{2}$ Also in line with the 1954 Convention, only those who have committed non-political crimes can be extradited (this topic will be addressed further on in the item on Political Asylum).

Territorial asylum may end when the individual leaves the host state, is naturalized, dies, or when the cause of the asylum ceases to exist, such as the end of a particular political regime in the state of origin, or expulsion from the State for reasons of national security or the protection of public order.

Worthy of mentioning, still, is that the General Assembly of United Nations approved in 1967 a Declaration on Territorial Asylum, which stated that it should be respected by states, which is a humanitarian and peaceful act, and that cannot be granted to perpetrators of war crimes, against peace and against humanity. However, as Mello points out (MELLO, 1994, p.930), only a declaration on territorial asylum has been approved, but it is not mandatory and allows the state to refuse entry of persecuted persons if this threatens national security, its population or in the event of a mass influx of persecuted persons, which makes it lose its reach.

Finally, it is noteworthy that although the subject is covered in the global system, it is clear that the institute gains prominence in the Latin American regional system not only because it was expressly consigned by the International Court of Justice, in the emblematic case involving Colombia. and Peru on Asylum Law, $1950 / 1951^{3}$, but also at the 1961 Vienna Convention on Diplomatic Relations, "que no

2 The Convention states that "No State has the right to request that another State restrict for the political
asylees or refugees the freedom of assembly or association which the latter State's internal legislation
grants to all aliens within its territory, unless such assembly or association has as its purpose fomenting
the use of force or violence against the government of the soliciting State. At the request of the interested
State, the State that has granted refuge or asylum shall take steps to keep watch over, or to intern at a
reasonable distance from its border, those political refugees or asylees who are notorious leaders of a
subversive movement, as well as those against whom there is evidence that they are disposed to join
it. Determination of the reasonable distance from the border, for the purpose of internment, shall depend
upon the judgment of the authorities of the State of refuge."
${ }^{3}$ Noteworthy are some aspects concerning the emblematic judgment of June 13,1951, in the Haya de 
incluyó el asilo diplomático en su articulado, al considerar la Comisión de Derecho Internacional de Naciones Unidas - que elaboró la referida Convención - que el asilo no tiene respaldo em el Derecho Internacional General." (TALAVERA; MOYANO, 2001, p.312).

\title{
3 THE POLITICAL ASYLUM
}

Political asylum, also called diplomatic or internal asylum, indicates the protection granted by a state outside its territorial sphere, and more precisely by an agent of a state, which operates within the territory of a foreign state to individuals who request such protection. ${ }^{4}$.

\begin{abstract}
la Torre case, between Colombia and Peru, and having Cuba as intervener, who reached the Court in the following circumstances: In November 1950, the Court defined the relations of law between Colombia and Peru on issues that these States had submitted to it, regarding diplomatic asylum in general and, in particular, the asylum granted on January 3 and 4, 1949 by the Colombian Ambassador in Lima to Victor Raul Haya de la Torre; she had considered that in this case the asylum had not been granted under the rules of the 1928 Havana Convention. After the sentence was handed down, Peru demanded that Colombia execute the same and that, to that end, the surrender of the refugee, improperly granted protection. Colombia replied that its delivery would contradict the judgment of November 20 and, in addition, would violate the Havana Convention; and filed the Court against a claim filed on December 13, 1950. In its application and during the proceedings, Colombia requested the Court to determine the manner of execution of the judgment of November 20,1950, and also to declare that execution of that judgment did not require the surrender of Haya de la Torre. Peru, for its part, also demanded to indicate how the sentence should be enforced by Colombia; to reject Colombian conclusions that she was not obliged to surrender Haya de la Torre; and then to declare that asylum should cease immediately after the judgment of 20 November and should in any event cease without delay, so that Peruvian justice could resume the normal course of its exercise. suspended. In the judgment in the Haya de la Torre case, the Court unanimously ruled that it is not one of its judicial functions to choose among the various ways in which asylum may end; by 13 votes to 1 , that Colombia is not obliged to surrender Haya de la Torre to the Peruvian authorities; unanimously, that asylum should have ceased following the pronouncement of the judgment of November 20, 1950, and should end.

${ }^{4}$ Para CUÉLLAR, 1997, p. 118, "el asilo diplomático puede definirse como el derecho que se concede a las representaciones diplomáticas de acoger temporalmente en su sede a perseguidos o delincuentes políticos, sustrayéndolos así de la soberanía del Estado receptor. El otorgamiento del asilo comporta, de acuerdo con las Convenciones que lo amparan, la obligación del Estado receptor a otorgar al perseguido un salvo-conducto que permita su salida del território".
\end{abstract}

Revista Jurídica Unicuritiba. Curitiba.V.04, n.57, p.1-22, Out-Dez. 2019

[Received/Recebido: Junho 07, 2018; Accepted/Aceito: Maio 02, 2019] 
The institute is grounded in humanitarian reasons, even though it is up to the State alone to grant it or not. Article 1 of the 1954 Diplomatic Asylum Convention in Caracas states:

"Asylum granted in legations, war vessels, and military camps or aircraft, to persons being sought for political reasons or for political offenses shall be respected by the territorial State In accordance with the provisions of this Convention".

As emphasized on another occasion (GUERRA, 2017), In the Rome of the Popes, jus quarteriorum was also widely used, until being abolished in 1693 by an agreement between Louis XIV and Pope Innocent XII. In the face of the transformation of the embassy block into the shelter of all types of criminals, this practice was declined on the European continent, reaching its end in the nineteenth century, in which the positivist doctrine opposes the claim that the sovereignty of countries would be hit by asylum granted by diplomats. In the same century, on the other hand, diplomatic asylum began to be practiced in Latin America, becoming a peculiar institute, because of the successive times of political upheaval that Latin American states went through. ${ }^{5}$.

However, there are caveats in what they do not recognize diplomatic asylum because they understand that the territorial state can qualify the nature of the crime, contrary to what is advocated in Article 4 of the 1954 OAS Convention on Political Asylum, according to which this is the responsibility of the State receiving the asylum seeker

Yet, despite Peru and the Dominican Republic opposing this provision of the

\footnotetext{
${ }^{5}$ In this sense BARBOZA, 2008, p. 722: "En la América Latina el asilo diplomático adquirió un rasgo de protección humanitaria. Varias circunstancias contribuyeron a la creación de este instituto muy particular a nuestra región: la admisión de cierto derecho de resistencia a la opresión, necesario por la existencia de dictaduras militares en el continente, la abundancia de revoluciones y golpes militares con el consiguiente surgimiento de gobiernos que encarcelaban a sus opositores políticos, la desconfianza al proceso judicial de estos gobiernos surgidos de interrupciones constitucionales y demás hicieron que se fuera gestando una costumbre regional en sentido de que existiría en principio la obligación de respetar el asilo diplomático otorgado y de conceder salvoconductos a los perseguidos políticos que tomaban refugio en Embajadas, normalmente de otros países latinoamericanos, bajo una suerte de reciprocidad".
} 
OAS Convention, the institution has had great success, resulting in several legal rules on the matter, such as the Asylum Convention, signed in Havana in 1928, applicable only political offenders; the Convention on Diplomatic Officials, also signed in Havana, which provides for the admission of political criminals; the Political Asylum Convention signed in Montevideo in 1928, which moved towards granting asylum only to those who committed political offenses and, finally, the 1954 Caracas Diplomatic Asylum Convention, which followed the same lines as the Montevideo Convention, concerning the granting of political asylum only in cases of political crimes, as provided for in its Article $3^{\text {rd }}$.

In regards to the practice of diplomatic asylum, it should be noted that it is not a peculiarity of the American continent itself, but of the Latin American states ${ }^{6}$, since some American countries, such as the United States, deny internal asylum, not recognizing it as an integral part of international law.

However, this does not mean that the United States does not practice diplomatic asylum under any circumstances. Despite denying domestic asylum as a right (the United States), there have been cases of granting it in the Latin American continent itself, as well as in Europe, especially from Cardeal Mindzentes, asylumseeker in Budapest, in Budapest from the Hungarian Revolution from 1956 to 1971.

As a matter of fact, although political asylum reaches its fullness in Latin America, nothing prevents countries from other continents from granting it as well. In contrast to territorial asylum, which presupposes the entry of a foreigner into the territory of the state of refuge, political asylum constitutes, in Rezek's (1996, p.219) view, it's an exception to the full competence that the State exercises over its own territory.

\footnotetext{
${ }^{6}$ In this meaning TALAVERA; MOYANO, 2001, p. 310: "La institución del asilo diplomático desarrollada en América Latina ha tenido como objetivos proteger la vida, la libertad y la integridad de personas perseguidas por delitos políticos y, asegurar en general, el respecto de los derechos fundamentales del hombre. Esta institución es regulada a través de una serie de normas convencionales y consuetudinarias de naturaleza regional."
} 
Asylum, in accordance with the OAS Convention of 1954, is granted in legations which, according to that Convention, constitute the headquarter of every ordinary diplomatic mission, the residence of the heads of mission and the places designated by them for that purpose, depending on the number of exiles ${ }^{7}$.

According to the lesson of Torres Gigena (MATTOS, 2002, p.271), both the embassy (residence of the head of the mission) and the chancellery (office of the mission) are valid for the purpose of granting asylum, unlike consulates, except for the consular section, which functions in the headquarter of the diplomatic mission. Also locations of asylum are military ships and aircraft, except when provisionally in shipyards, armories or workshops for repair

Article 1 st of the previously mentioned Convention states that only persons persecuted for political offenses may enjoy diplomatic asylum. This is the great controversy regarding the definition of political crimes, a subject that needs further clarification because the effects of their characterization are closely linked to nonextradition, since the political criminal is not extraditable.

In the International System, war crimes, crimes against peace and crimes against humanity are not considered political crimes either. It should also be emphasized that it is up to the refuge state to characterize crime as political or common, a fact that often depends on the political or economic interests of the receiving state.

If the State refuses to grant asylum, it is under no obligation to give reasons for its refusal, given that there is no obligation on the part of the States to grant asylum.

\footnotetext{
${ }^{7}$ Artigo I of the Conventionde 1954: "Asylum granted in legations, war vessels, and military camps or aircraft, to persons being sought for political reasons or for political offenses shall be respected by the territorial State In accordance with the provisions of this Convention. For the purposes of this Convention, a legation is any seat of a regular diplomatic mission, the residence of chiefs of mission, and the premises provided by them for the dwelling places of asylees when the number of the latter exceeds the normal capacity of the buildings. War vessels or military aircraft that may be temporarily in shipyards, arsenals, or shops for repair may not constitute a place of asylum.".
} 
In addition, the asylum is not offered, but requested by the person concerned, as proclaimed by Mattos (2002, p.272).

Asylum can only be granted in cases of urgency, that is to say, in cases of persecution of the individual by unrestrained persons or multitudes, by the authorities themselves or in danger of being deprived of their life and liberty for reasons of political persecution for the time strictly so that the person who has received the asylum leaves the country with the guarantees granted by the Government of the territorial state, the so-called safe conduct, in order to ensure the life, liberty and physical and personal integrity of that person be detained by the legal authorities, nor be landed anywhere in the territorial state. It is also worth mentioning that once the asylum is removed, it will not be landed anywhere in the territorial state.

Finally, diplomatic asylum may end in the resignation, surrender of the asylum, but only on condition that the crime is characterized as common, not political; by death; by its escape or its departure from the state.

The Institute of Diplomatic Asylum, in its essentials, is due more to considerations of opportunities and courtesy than to the principles of law. In summary (SOARES, 2002, p.383), the main provisions on diplomatic asylum contained in the 1954 Convention can be identified as:

a) asylum is granted to persons persecuted for political reasons or offenses;

b) the right to grant asylum belongs to the State, which is not obliged to grant it or to declare why it denies it;

c) diplomatic asylum is not granted to persons accused, prosecuted or convicted of common offenses;

d) It is for the receiving State to classify the nature of the offense or grounds for persecution;

e) asylum presupposes cases of urgency and for the strictly indispensable time for the asylum seeker to leave the country, with the guarantees agreed upon by the 
territorial State, and the receiving State shall specify the urgency;

f) the territorial State may at any time require the asylum to be withdrawn from the country, for which it shall grant a safe conduct and the necessary guarantees to do so;

g) If the safe conduct has been granted, the receiving State may request the removal of the person who has received asylum to foreign territory, and the territorial State is obliged to grant the necessary guarantees immediately, except in cases of force majeure;

h) Asylum seekers may not be landed anywhere in the territorial State, anywhere near it, except for the necessity of transportation;

i) the receiving State is not obliged to grant stay to the person who has been granted asylum, but may not send him or her back to his or her country of origin, unless the asylum expressly wishes it;

j) Political asylum is not subject to reciprocity and anyone can be under their protection.

Undoubtedly, the American continent has made a great contribution to its codification, especially the 1954 Caracas Convention. Not only that, but in a recent statement of the Inter-American Court of Human Rights, through Advisory Opinion no. $25 / 2018^{8}$, the body had the opportunity to outline several important aspects of asylum, where general considerations will be given.

\section{THE ASYLYM RIGHT AS SEEN BY THE INTER-AMERICAN HUMAN RIGHTS COURT FROM OC N. 25/18}

The Inter-American Court of Human Rights, in response to the request made

${ }^{8}$ Avaliable at http://www.corteidh.or.cr/cf/Jurisprudencia2/index.cfm?lang=es 
by the Republic of Ecuador, issued Advisory Opinion no. 25, dated 30 May 2018, on the scope of the asylum institute, in particular aspects of legality and recognition as a human right to be observed for all persons in accordance with the principle of equality and non-discrimination (provided for in Articles 2.1, 5 and 26 of the International Covenant on Civil and Political Rights), the pro persona principle and the obligation to respect human rights, as well as Articles 31 and 32 of the Vienna Convention on the Law of Treaties, Article 29 of the American Convention on Human Rights, Articles 28 and 30 of the Universal Declaration of Human Rights, and Article 5 of the Geneva Convention on the Status of Refugees..

At the time, it was questioned whether it could be understood that Article 22.7 of the American Convention and Article XXVII of the American Declaration protect and guarantee the human right to seek and receive asylum for the different modalities, forms or categories of asylum contemplated in international law (including diplomatic asylum), in accordance with Article 14.1 of the Universal Declaration of Human Rights, the 1951 Geneva Convention on Refugee Status and its 1967 New York Protocol, as well as the regional asylum conventions and rules of domestic law OAS Member States? What international obligations derive from the American Convention and the American Declaration in a situation of diplomatic asylum for the receiving State?

The Court emphasized that these two questions sum up the most important ones formulated by Ecuador. The right to seek and receive asylum in accordance with Articles 22.7 of the American Convention on Human Rights and XXVII of the American Declaration of the Rights and Duties of Man

It was evident that the human right on which the Inter-American Court focused its interpretative work was the "right of asylum" and its various regulatory components and, at the end, presented its understanding on the classification of asylum, distinguishing political asylum, which coincides with the so-called "tradition of Latin American asylum" and asylum under refugee status according to the traditional 
definition and the expanded regional definition of the Cartagena Declaration.

Moreover, according to where protection is granted, strict meaning of asylum can be classified as territorial asylum and diplomatic asylum and noted that the nature of diplomatic functions and the fact that the legation is located in the territory of the receiving state introduces a difference significant with territorial asylum.

The Inter-American Court further considered that asylum, being a comprehensive concept, in accordance with the various inter-American conventions on the subject (in accordance with Article 22.7 of the American Convention and Article XXVII of the American Declaration), covers both territorial and diplomatic asylum.

It asserted that Article 22.7 of the Convention refers to the "case of persecution for political or political related criminal offenses" and could therefore, in principle, cover both forms of political asylum, as that requested in the territory of the host State or requested in a diplomatic legation.

The Court found that in making a literal interpretation, together with the context of Article 22.7 of the Convention and XXVII of the Declaration, referring to the international conventions on the subject itself, it was understood that the term "foreign territory" clearly refers to protection derived from territorial asylum, unlike diplomatic asylum, whose scope of protection is legations, among other places.

Likewise, it drew on the preparatory work of the American Declaration to confirm the interpretation made, since those used in the Convention do not expressly refer to the reasons why the terminology "in foreign territory" would have been adopted.

As a result of this verification, it was concluded that the states' will was to exclude the diplomatic asylum figure from a person protected under these international standards, while maintaining its regulation in line with the Latin American conventions on asylum, that is, in the understanding that constitutes a prerogative of the State, having manifested as followed:

Revista Jurídica Unicuritiba. Curitiba.V.04, n.57, p.1-22, Out-Dez. 2019

[Received/Recebido: Junho 07, 2018; Accepted/Aceito: Maio 02, 2019] 
La Corte consideró que la expresa intención de no incluir al asilo diplomático dentro de la esfera del sistema interamericano de derechos humanos pudo deberse a la voluntad, expresada aún en el marco de este procedimiento, de concebir el asilo diplomático como un derecho del Estado, o en otros términos como una prerrogativa estatal, y así conservar la potestad discrecional para su otorgamiento o denegación en situaciones concretas. Además, la Corte sostuvo que, conforme al derecho internacional público no existe acuerdo universal respecto a la existencia de un derecho individual a recibir asilo diplomático, a pesar de que esta figura podría constituir un mecanismo efectivo para proteger a los individuos ante circunstancias que tornan difícil la vida democrática en un país determinado. Esta falta de consenso internacional, no implica desconocer que, a veces, el recurso al asilo diplomático no puede ser totalmente descartado, ya que los Estados conservan la facultad de otorgarlo, al constituir una potestad soberana de los mismos. En efecto, las personas han buscado asilo en las misiones diplomáticas por siglos, y los Estados, a su vez, han otorgado alguna forma de protección a individuos perseguidos por razones políticas o que enfrentan una amenaza inminente a su vida, libertad, seguridad y/o integridad, no siempre reconociendo el asilo diplomático, sino en muchas ocasiones recurriendo a negociaciones de carácter diplomático. En esta medida, de conformidad con el derecho internacional, el asilo diplomático consiste en una práctica humanitaria con la finalidad de proteger derechos fundamentales de la persona, la cual ha sido otorgada con el fin de salvar vidas o prevenir daños a derechos fundamentales ante una amenaza inminente. En conclusión, la Corte interpretó que el asilo diplomático no se encuentra protegido bajo el artículo 22.7 de la Convención Americana o el artículo XXVII de la Declaración Americana. En definitiva, el derecho a buscar y recibir asilo en el marco del sistema interamericano se encuentra configurado como un derecho humano a buscar y recibir protección internacional en territorio extranjero, incluyendo con esta expresión el estatuto de refugiado según los instrumentos pertinentes de las Naciones Unidas o las correspondientes leyes nacionales, $y$ el asilo territorial conforme a las diversas convenciones interamericanas sobre la materia. Finalmente, la Corte estimó pertinente pronunciarse sobre el argumento referido a que el asilo diplomático constituiría costumbre regional y señaló que el elemento de la opinio juris necesario para la determinación de una norma consuetudinaria no se encontraba presente, a pesar de la práctica de los Estados de otorgar en determinadas situaciones el asilo diplomático o bien de otorgar algún tipo protección en sus legaciones (CORTE IDH, 2018).

Accordingly, the Court considered that the granting of diplomatic asylum and its scope should be governed by the interstate conventions that govern it, as well as by the provisions of domestic law. That is, states that have signed multilateral or bilateral diplomatic asylum agreements, or have recognized it as a fundamental right in their domestic regulations, are bound by the terms set forth in such regulation. In 
this regard, the Court considered it pertinent to emphasize that states have the power to grant diplomatic asylum, as an expression of their sovereignty, which is part of the logic of the so-called "tradition of Latin American asylum".

Following this understanding, the Court emphasized that while diplomatic asylum is not foreseen under the inter-American system, other human rights obligations still exist for the host state and, in this case, for third states, because of the risk that they may face. suffer people who seek a legation for protection. ${ }^{9}$

The Court also defined as an integral component of the right to seek and receive asylum the State's obligation not to return a person to a territory in which he or she is at risk of being persecuted.

However, the principle of "non-return" is not an exclusive component of international refugee protection as, as international human rights law has evolved, it has found a solid foundation in the various instruments and interpretations of human rights.

Indeed, the principle of "non-return" is not only fundamental to the right to asylum but also as a guarantee of various non-derogable human rights, since it is precisely a measure whose purpose is to preserve the life, liberty or integrity of protected person.

Therefore, the Court considered that the scope of protection against nonreturn is not limited to the person who is in the territory of the State, but also to the States in an extraterritorial manner, whenever the authorities exercise their authority or effective control over such matters. as may be the case with legations, who by

\footnotetext{
${ }^{9}$ CORTE IDH, 2018: "La Corte concluyó que los Estados de acogida están obligados por lo dispuesto en el artículo 1.1 de la Convención, en tanto estén ejerciendo control, autoridad o responsabilidad sobre alguna persona, con independencia de que ésta se encuentre en el territorio terrestre, fluvial, marítimo o aéreo de dicho Estado. Por lo tanto, la Corte consideró que las obligaciones generales que establece la Convención Americana son aplicables a las actuaciones de los agentes diplomáticos desplegados en el territorio de terceros Estados, siempre que pueda establecerse el vínculo personal de jurisdicción con la persona concernida."
} 
their very nature are in the territory of another state with their consent. It was further stated that:

Es por ello que la devolución, como concepto autónomo y englobante, puede abarcar diversas conductas estatales que impliquen poner a la persona en manos de un Estado en donde su vida, seguridad y/o libertad estén en riesgo de violación a causa de persecución o amenaza de la misma, violencia generalizada o violaciones masivas a los derechos humanos, entre otros, así como donde corra el riesgo de ser sometida a tortura u otros tratos crueles, inhumanos o degradantes, o a un tercer Estado desde el cual pueda ser enviada a uno en el cual pueda correr dichos riesgos (devolución indirecta). Tales conductas incluyen, entre otras, la deportación, la expulsión o la extradición, pero también el rechazo en frontera, la no admisión, la interceptación en aguas internacionales y el traslado informal o "entrega". Esta afirmación se asienta en la propia redacción del artículo 22.8 de la Convención Americana, que establece que "en ningún caso" el extranjero puede ser expulsado o devuelto a otro país, es decir, que no tiene condiciones territoriales sino que puede incluir el traslado o la remoción de una persona entre jurisdicciones (CORTE IDH, 2018).

Since that time, the Court has ruled that the principle of "no return" is enforceable by any foreign person, including those seeking protection, over whom the State in question is exercising its authority or over its effective control (whether in its terrestrial, river, sea or air territory), covering acts performed by migratory and border authorities, as well as acts performed by diplomatic officials ${ }^{10}$. The InterAmerican Court of Human Rights has decided on the subject as:

El Estado de acogida debe, por tanto, arbitrar todos los medios necesarios para proteger a la persona en caso de un riesgo real a la vida, integridad, libertad o seguridad si es entregada o removida al Estado territorial o si existe un riesgo de que ese Estado a su vez pueda expulsar, devolver o

${ }^{10}$ CORTE IDH, 2018: "De todo lo anteriormente expuesto se deriva que, en el marco del principio de no devolución, son exigibles para el Estado de acogida, bajo cuya jurisdicción está la persona que ha solicitado protección en una sede diplomática, algunas obligaciones específicas, en cuanto a la evaluación individualizada del riesgo y medidas adecuadas de protección, incluyendo aquellas contra la detención arbitraria. Así, la Corte consideró que, en el marco de la Convención Americana, es exigible la entrevista de la persona y una evaluación preliminar del riesgo de devolución." 
extraditar posteriormente a la persona a otro Estado donde exista ese riesgo real. La Corte estimó, además, que la situación jurídica de la persona tampoco puede quedar en un limbo o prolongarse indefinidamente. La Corte sostuvo que el hecho de que la persona no pueda ser devuelta no implica per se que el Estado deba necesariamente otorgar el asilo en su sede diplomática, sino que subsisten otras obligaciones que imponen al Estado adoptar las medidas diplomáticas, incluida la solicitud al Estado territorial de expedir un salvoconducto, o de otra índole que estén bajo su autoridad y, de conformidad con el derecho internacional, para asegurar a los solicitantes la garantía de los derechos convencionales (CORTE IDH, 2018).

Thus, it was stressed by the Court that the duty of cooperation between states in the promotion and observance of human rights is presented as a rule of an erga omnes character and, therefore, must be applied and enforced by all states, and still binding in international law.

For that reason, in accordance with the underlying collective guarantee mechanism provided for in the American Convention, it is for all states of the interAmerican system to cooperate with each other to fulfill their international obligations, both regional and universal.

\section{CONCLUSION}

The right to asylum still has a very incipient treatment, since the fact that it is considered a State's right ${ }^{11}$, and not the right of the individual, despite the essential

11 By the way, see Ext 1008 / CB - Colombia, whose rapporteur was Minister Gilmar Mendes, in a
judgment given by the Full Court on $21-3-2007$, which reads: "Extradition: Colombia: Crimes Related to
the Participation of the extraditing - then priest of the Catholic Church - in military action of the
Revolutionary Armed Forces of Colombia (FARC). Question of order. Recognition of the refugee status
of the extradite, by decision of the National Committee for Refugees - CONARE: thematic relevance
between the motivation of granting the refuge and the object of the extradition request: application of
Law 9.474 / 97 , art. 33 (Refugee Statute), whose constitutionality is recognized: absence of violation of
constitutional principle of separation of powers. 1 . According to art. 33 of L. $9474 / 97$, the administrative
recognition of refugee status as long as it lasts is by definition elusive of extradition having implications
for the reasons for its acceptance. 2 . The law that reserves to the Executive Power - which is 
purpose of protecting the human person, is a real delay and a contradiction.

This paradox is most evident when confronted with the State's prerogative to grant asylum or not in relation to the Universal Declaration of Human Rights, which states that "every man who is a victim of persecution has the right to seek and to enjoy asylum in other countries".

Legale and Sousa, when discussing this issue, affirm that from the point of view of constitutional law the difference does not seem to be so relevant, because the important thing, in this view, refers to the protection of the human being in international relations. Moreover, as the persecution arises from political opinions, it ends up touching on asylum matters, with no significant differences. According to the authors ${ }^{12}$, in its final considerations, it is not possible to state whether the right to asylum is an act of state sovereignty, being a State faculty to grant it or not, because if the grant is a humanitarian practice, it would imply a subjective right of the asylum seeker.

Habermas, in an interview with Deutsche Welle given at the Library of Congress in Washington - United States, addressing issues that affect modern society, such as the migratory crisis, cultural and religious conflicts and asylum, stressed: "the right to asylum It is a human right, and anyone seeking asylum must be treated fairly and, where appropriate, must be upheld with all the consequences."

constitutionally responsible for making decisions that have an impact on the international relations of the State - has the exclusive power to grant asylum or refuge. 3 . The fact that the prejudice to the proceeding arises from the act of another Power - provided that it is within its competence - does not mean an invasion of the area of the Judiciary. 4. Extradition request not known, extinguished the process, without judgment of the merits and determined the release of the extradite. 5. In which case the constitutional prohibition of extradition for a political crime would include any kind of criminal offense against a person or property in the context of a politically motivated rebellion (Ext. 493). ".

12 LEGALE; SOUSA, 2008 p. 3-35: "Por isso mesmo, o asilo como princípio constitucional, caracterizado por possuir núcleo (dignidade da pessoa humana/prevalência dos direitos humanos na ordem internacional/não concessão de extradição por crimes políticos ou de opinião) e camada ponderável (decorrente da soberania). Afinal de contas, deve-se permitir uma fundamentação mais confiável e racional às decisões dos magistrados e das instâncias administrativas competentes, tanto quanto realizar a vigília atenta da soberania estatal para que, nesses casos, os direitos fundamentais, tão caros ao Estado Democrático de Direito, não sejam solapados das relações internacionais." 
(RECCIUS, 2018).

It is quite true that granting asylum is often confused with the refugee's legal situation. In this sense, Fischel Andrade in a study carried out presented didactic scheme for understanding them:

\begin{abstract}
A) 'asylum' is a regional legal institute, first envisioned as a regional instrument, by the 1889 Montevideo Treaty on International Criminal Law, currently regulated by various regional instruments. 'Refuge' is a global legal institute envisioned by the 1951 Convention and the 1967 Protocol, which developed from the 1922 Agreement on the Issuing of Identity Certificates for Russian Refugees. Only recently refuge found expression in conventional and unconventional regional instruments - respectively the 1969 OAU Convention and the 1984 Cartagena Declaration; b) 'asylum' is a legal institute that can be applied, and thus to provide protection, within the borders of 'asylumproducing' countries, such as diplomatic asylum. The 'refuge' can only be considered if the person concerned has crossed the border of his or her home country; c) to be considered an "asylum" the individual must be persecuted in act exercitu. For a 'refugee' it is sufficient to have a 'well-founded fear of persecution' which has not necessarily materialized yet; d) an asylum is persecuted for political crimes. The definition of 'refugee' is broader as it mentions political opinions and, in addition, encompasses other motives, namely race, religion, nationality and membership of a particular social group; e) as regards asylum seekers, no organization has been established to oversee and collaborate in the implementation of asylum instruments; This is not the case for 'refugee' instruments, where UNHCR plays an important and significant role in these activities, in addition to developing and disseminating the principles applicable to refugee protection; f) 'asylum' instruments do not contain cessation or exclusion clauses, which are envisioned in 'refuge' instruments; and; g) The granting of the legal condition of asylum is constitutive in nature. Obtaining the legal status of 'refugee', in turn, is by means of a declaratory act whereby the state recognizes the individual as a refugee (ANDRADE, 2000, p.82-84).
\end{abstract}

Undoubtedly, the subject matter is currently relevant, and should therefore take a closer look at the domestic law of the national states, the inter-American system, and also the international, and the best understanding of its application and observance is certain. of the institute should be one aimed at safeguarding and wellbeing of the human person.

Revista Jurídica Unicuritiba. Curitiba.V.04, n.57, p.1-22, Out-Dez. 2019

[Received/Recebido: Junho 07, 2018; Accepted/Aceito: Maio 02, 2019] 


\section{REFERENCES}

ANDRADE, José H. Fischel de. Regionalização e harmonização da definição de refugiado e dos procedimentos para determinação da condição de refugiado no âmbito do Mercosul. In: CASELLA, Paulo Borba. Mercosul: globalização e integração regional. Rio de Janeiro: Renovar, 2000.

BARBOZA, Julio. Derecho internacional público. 2. ed. Buenos Aires: Zavala, 2008.

CAVARZERE, Thelma Thais. Direito internacional da pessoa humana. Rio de Janeiro: Renovar, 2001.

CORTE IDH. La institución del asilo y su reconocimiento como derecho humano en el sistema interamericano de protección (interpretación y alcance de los artículos 5, 22.7 y 22.8, en relación con el artículo 1.1 de la Convención Americana sobre Derechos Humanos). Opinión Consultiva OC-25/18 de 30 de mayo de 2018. Serie A No. 25. Disponível em http://www.corteidh.or.cr/cf/Jurisprudencia2/index.cfm?lang=es. Acesso em 07/09/2018.

CUÉLLAR, Javier Pérez. Manual de derecho diplomático. México, DF: Fondo de Cultura Económica, 1997.

GUERRA, Sidney. Curso de direito internacional público. 11. ed. São Paulo: Saraiva, 2017.

- O sistema interamericano de proteção dos direitos humanos e 0 controle de convencionalidade. São Paulo: Atlas, 2013.

. Direitos humanos: curso elementar. 5. ed. São Paulo: Saraiva, 2017.

. Direito internacional dos direitos humanos. 2. ed. São Paulo: Saraiva, 2015

HABERMAS, Jürgen. Direito de asilo é direito humano. Disponível em https://www.cartacapital.com.br/internacional/direito-de-asilo-e-direito-humano-dizhabermas-4676.html. Acesso em 08/09/2018.

LEGALE, Siddharta; SOUSA, Adriano Correa de. Asilo político: uma proposta alternativa sob a ótica constitucional. RDM Universidade Federal Fluminense, v. 1, 
p. 3-35, 2008.

MATTOS, Adherbal Meira. Direito internacional público. Rio de Janeiro: Renovar, 2002.

MELLO, Celso Albuquerque. Direito constitucional internacional. Rio de Janeiro: Renovar, 1994.

TALAVERA, Fabián Novak; MOYANO, Luis Garcia Corrochano. Derecho internacional público. Tomo II. Lima: Fondo Editorial de la Pontifica Universidad Católica, 2003.

RECCIUS, Stefan. "Direito de asilo é direito humano", diz Habermas. In: CartaCapital. 2018. Avaliable at https://www.cartacapital.com.br/internacional/direito-de-asilo-edireito-humano-diz-habermas-4676.html. Acess in 08/09/2018.

REZEK, José Francisco. Direito internacional público: curso elementar. 6. ed. São Paulo: Saraiva, 1996.

SOARES, Guido Fernando Silva. Curso de direito internacional público. São Paulo: Atlas, 2002. 